\title{
PELATIHAN PENGOLAHAN DAN PENGEMASAN TEPUNG SAGU MENJADI STIK SAGU KEJU DI KAWASAN RUMAH PANGAN LESTARI (KRPL) DESA MANUKAYA KECAMATAN TAMPAKSIRING KABUPATEN GIANYAR
}

\author{
A. A. Istri Sri Wiadnyani ${ }^{1}$, I D.G Mayun Permana ${ }^{2}$, I W.R. Widarta ${ }^{3}$, I D.P. Kartika Pratiwi ${ }^{4}$
}

\begin{abstract}
ABSTRAK
Desa Manukaya termasuk salah satu desa yang terletak di Kecamatan Tampaksiring, Kabupaten Gianyar. Jarak desa tersebut dari kota Denpasar adalah $\pm 40 \mathrm{~km}$ dengan waktu tempuh \pm 1 jam. Mata pencaharian sebagian besar penduduk Desa Manukaya adalah petani.. Salah satu hasil pertanian yang sedang berkembang di Desa Manukaya adalah pertanian sagu dan sudah terdapat kelompok Tani (KT) 'Abian sari' yang terdiri dari 18 orang petani sagu. Permasalahannya pada saat panen raya, produksi sagu berlimpah sehingga harga jual menjadi rendah karena tidak semua dapat diserap oleh pasar diharapkan kelompok PKK dan KT dapat bersinergi dalam mensuplai dan mengolah sagu menjadi produk olahan yang bermanfaat dan bernilai gizi tinggi. Metode pemecahan masalah yang digunakan berupa pengenalan dan pelatihan pembuatan produk olahan tepung sagu menjadi stik sagu keju dan pengemasan sampai pada pelabelannya. Hasil yang didapatkan bahwa kegiatan penyuluhan, pelatihan serta pendampingan pembuatan produk produk olahan tepung sagu menjadi stik sagu keju berjalan dengan baik dan sesuai rencana dimana KT Abian Sari sudah mampu memproduksi produk olahan tersebut dengan baik. Pengemasan dan pelabelan pada produkpun sudah dapat dikerjakan dengan baik dan dihasilkan produk dengan identitas dan penampilan yang menarik
\end{abstract}

Kata kunci : Kelompok Tani Abian Sari, Desa Manukaya, Tampaksiring, Tepung Sagu, Stik Sagu Keju

\begin{abstract}
Manukaya Village is one of the villages located in Tampaksiring District, Gianyar Regency. The distance of the village from Denpasar city is $\pm 40 \mathrm{~km}$ with a travel time of \pm 1 hour. The livelihood of the majority of the population of Manukaya Village is farmers. The area of rice fields in Manukaya Village is 141 hectares and the plantations and fields are $891.79 \mathrm{Ha}$. One of the agricultural products that is developing in Manukaya Village is sago plantation and there has been a farmer group called 'KelompokTani Abian Sari' consisting of 18 sago farmers. Geographical location and temperature and environment are very suitable for the growth of sago plants in Manukaya Village. The Farmer Group is able to produce 800 to $2000 \mathrm{~kg} /$ month of sago flour from 4 to 5 Sago trees. Abian Sari women-farmer group in Manukaya Village only processes sago into flour to be sold or only processed into wet snacks, such as ongol-ongol, layer cakes for family consumption or sold in markets around the village. The problem is that sago production is abundant at the time of the harvest, so the selling price is low because not all of it can be absorbed by the market. That is why, it is necessary to process sago flour into a more commercial product of high nutritional value. Problem solution method used in this research was introduction and training of processing sago flour to cheese sago sticks and its packaging and labeling. Counseling, training and assistance activities for processing sago flour to cheese sago sticks run well in which KT Abian Sari can produce the processed product well. Packaging and labeling of the product may be also done well and resulting in product with interesting identity and appearance.
\end{abstract}

Keywords: Farmer Group Abian Sari. Manukaya village, Tampaksiring, Sago flour, Cheese Stik

\footnotetext{
${ }^{1}$ Staff Pengajar Program Studi Ilmi dan Teknologi Pangan, Fakultas Teknologi Pertanian, Universitas Udayana, sriwiadnyani@unud.ac.id

${ }^{2}$ Staff Pengajar Program Studi Ilmi dan Teknologi Pangan, Fakultas Teknologi Pertanian, Universitas Udayana,

${ }^{3}$ Staff Pengajar Program Studi Ilmi dan Teknologi Pangan, Fakultas Teknologi Pertanian, Universitas Udayana,

${ }^{4}$ Staff Pengajar Program Studi Ilmi dan Teknologi Pangan, Fakultas Teknologi Pertanian, Universitas Udayana,
} 


\section{PENDAHULUAN}

Desa Manukaya termasuk salah satu desa yang terletak di Kecamatan Tampaksiring, Kabupaten Gianyar. Jarak desa tersebut dari kota Denpasar adalah $\pm 40 \mathrm{~km}$ dengan waktu tempuh \pm 1-1,5 jam. Kecamatan Tampaksiring terdiri dari 8 desa yaitu Manukaya, Pejeng, Pejen kangin, Pejeng Kaja, Pejeng Kawan, Pejeng Kelod, Sanding dan Tampaksiring. (Anon, 2017b). Luas wilayah Desa Manukaya 1496 Km2 dimana tanah persawahan $141 \mathrm{Km} 2$ dan tegalan 891,79 Km2 dengan jumlah penduduk 11.519 jiwa yang terdiri dari pria 5.920 jiwa dan wanita 5.599 jiwa dengan total usia produktif adalah 3549 jiwa pada tahun 2015 (Anon, 2017a).

Tahun 2015 mata pencaharian penduduk adalah $18 \%$ bertani, sedangkan data tahun 2016 terdapat 2059 petani, peternakan 456, perkebunan 178, industri 976 dan perdagangan 998 orang. Karena didukung oleh letak geografis di dataran tinggi, salah satu hasil pertanian yang sedang berkembang di Desa Manukaya adalah pertanian Sagu dan sudah terdapat kelompok Tani ( KT) Abian Sari yang bergerak pada pertanian Sagu. Letak geografis dan suhu serta lingkungan yang sesuai untuk pertumbuhan Sagu di Desa Manukaya (Anon, 2017c)

Sagu merupakan bahan makanan bernutrisi dengan kandungan karbohidrat tinggi. Dalam 100 gr tepung sagu terdapat 355 kalori, 94 gr karbohidrat, 0,2 gr protein, 0,5 gr serat, $10 \mathrm{mg}$ kalsium, 1,2 $\mathrm{mg}$ besi dan sebagian kecil lemak, karoten, tiamin dan asam askorbat. Mengkonsumsi Tepung Sagu bukan hanya untuk memuaskan lidah dan mengenyangkan perut, karena ternyata banyak manfaat yang berguna dari Sagu seperti mampu menghambat laju peningkatatan kadar glukosa dalam darah karena kandungan serat yang tinggi dan juga sebagai prebiotik yang berfungsi menjaga kesehatan saluran pencernaan (Johan, 2014)

Selain memiliki potensi hasil pertanian Sagu tiram yang besar, Desa Manukaya juga merupakan daerah yang dicanangkan oleh pemerintah Kabuapten Gianyar sebagai Kawasan Rumah Pangan Lestari (KRPL) yang merupakan himpunan Rumah pangan lestari (RPL) yaitu rumah tangga dengan prinsip pemanfaatan pekarangan yang ramah lingkungan dan dirancang untuk pemenuhan kebutuhan pangan dan gizi keluarga, diversifikasi pangan berbasis sumber daya lokal, pelestarian tanaman pangan untuk masa depan serta peningkatan pendapatan yang pada akhirnya meningkatkan kesejahteraan masyarakat. Adanya usaha pengolahan Tepung Sagu menjadi produk pangan, maka produk-produk olahan tersebut dapat dipasarkan didaerah objek wisata tersebut sebagai produk khas oleh-oleh dari Desa Manukaya bagi wisatawan, sehingga dapat menjadikan Desa Manukaya sebagai sentral pertanian Sagu, Kawasan Rumah Pagan Lestari di Gianyar (KRPL), industri pengolahan Sagu serta pariwisata yang berpengaruh di Bali.

Terdapat Kelompok Tani Sagu (KT Abian sari ) yang berjumlah 25 orang yang mampu memproduksi 800- $2000 \mathrm{~kg}$ tepung sagu/bulan dari 4-5 batang pohon sagu tetapi hanya menjual sagu dalam bentok olahan tepung sagu saja tanpa dilakukan pengolahan lebih lanjut. Di Desa Manukaya terdapat kelompok PKK dan ibu rumah tangga yang melakukan kegiatan menjahit ataupun membuat jajanan tradisional dari tepung sagu sepert kue lapis, jaje ongol-ongol pada saat upacara keagamaan yang tentu saja penganan tradisional yang bersifat basah/semi basah sehingga memeliki umur simpan yang relatif pendek, padahal ada kelompok petani Sagu yang mampu memproduksi Sagu yang berlimpah yang nantinya dapat diharapkan PKK dan KWT Abian Sari dapat bersinergi dalam mensuplai dan mengolah Sagu menjadi produk olahan yang bermanfaat dan bernilai gizi tinggi.

Sagu dapat dijadikan sebagai alternatif dalam mengembangkan potensi swadaya masyarakat dalam berwirausaha maka dipandang perlu untuk memberikan pengetahuan tambahan tentang pengolahan dan teknik pengemasan tepung sagu menjadi stik sagu keju. Stik Sagu keju merupakan sejenis makanan ringan cemilan yang mudah dibuat dan memperguanakan bahan-bahan yang sederhana yang kaya akan sumber karbohidrat, protein dan sebagai pangan fungsinal. Oleh karena itu, penyuluhan, pelatihan, dan pengenalan proses pengolahan lanjutan dari Sagu menjadi 
PELATIHAN PENGOLAHAN DAN PENGEMASAN TEPUNG SAGU MENJADI STIK SAGU KEJU DI KAWASAN RUMAH PANGAN LESTARI (KRPL) DESA MANUKAYA KECAMATAN TAMPAKSIRING KABUPATEN GIANYAR

produk-produk olahan yang mempunyai nilai ekonomis yang lebih tinggi merupakan langkah yang tepat.

\subsection{Tujuan Kegiatan}

Memperkenalkan teknologi pengolahan tepung sagu mennjadi stik sagu keju dikuti dengan teknik pengemasan (packing) dan teknik pelabelan (labeling) sehingga menjadi produk-produk yang memiliki nilai ekonomis lebih tinggi sekaligus merupakan makanan pendamping yang bergizi karena kandungan karbohidrat, pati dan protein. Di samping dengan pelatihan dan praktek langsung, masyarakat diharapkan dapat meningkatkan ketrampilannya dan memiliki pengetahuan lebih mendalam mengenai teknologi pengolahan Sagu menjadi produk-produk makanan untuk diversifikasi pangan yang pada akhirna akan meningkatkan pendapatan keluarga

\subsection{Manfaat Kegiatan}

1. Peningkatan pengetahuan dan ketrampilan berupa teknologi tepat guna khususnya dalam pengolahan tepung sagu menjadi stik sagu keju yang kaya kandugan gizi karbohidrat dan protein yang berguna bagi kesehatan petani dan masyarakat Desa Manukaya, TampaksiringGianyar.

2. Manfaat bagi pemerintah daerah adalah perolehan masukan dalam bentuk teknologi pengolahan Sagu menjadi stik sagu keju serta upaya ikut serta memberdayakan potensi masyarakat bagi pembangunan Desa Manukaya-Gianyar

\section{METODE PELAKSANAAN}

1. Memberikan pelatihan dan penyuluhan tentang cara pengolahan Sagu menjadi stik sagu keju. Pelaksanaan pelatihan ini di samping diberikan secara lisan dengan pemaparan cara pembuatan stik sagu keju juga dilengkapi diagram alir proses pengolahan stik sagu keju, juga diberikan brosur/makalah mengenai teknologi pengolahan Sagu yang memiliki kandungan karbohidrat dan protein yang tinggi.

2. Memberikan praktek kegiatan pengolahan Sagu menjadi stik sagu keju yang siap dikonsumsi dan dipasarkan.

3. Memberikan teknik pengemasan dan teknik pelabelan pada produk stik sagu keju sehingga dapat meningkatkan umur simpan produk dan juga meningkatkan nilai ekonomisnya

4. Melakukan pendampingan, monitoring dan evaluasi selama proses pengolahan (produksi) dan pemasaran produk olahan tepung sagu untuk mengetahui kendala-kendala yang dihadapi mitra sehingga nantinya mitra bisa berproduksi secara mandiri

\section{HASIL DAN PEMBAHASAN}

\subsection{Penyuluhan Produk Olahan Tepung Sagu}

Pelaksanaan pengabdian melalui ceramah dan pelatihan pembuatan produk olahan tepung sagu guna memperkenalkan dan memberikan pengetahuan tambahan kepada ibu-iburumah tangga maupun kepada KT Abian Sari tentang teknologi tepat guna yag sederhana dalam pengolahan tepung sagu menjadi stik sagu keju sehingga ibu-ibu maupun anggota KT dapat menerapkannya di rumah tangga ataupun kelompoknya sekaligus mempertahankan nilai ekonomis tepung sagu disaat panen raya. Program ini mendapat sambutan yang baik. Hal ini terlihat dari tingginya antusias peserta yang hadir. 


\section{Ceramah}

Pemberian ceramah kepada Kelompok Tani Abian Sari serta ibu rumah tangga di Desa Manukaya tentang cara pembuatan stik sagu pada tanggal 10 Juli 2018. Ceramah dilakukan terhadap 20 orang. Peserta Pelatihan terlihat sangat antusias dan aktif mengajukan pertanyaan.

\section{Pelatihan}

Program ini mendapat sambutan yang baik dari ibu-ibu PKK dan anggota Kelompok Tani Abian Sari. Hal ini terlihat dari tingginya antusias peserta pada saat pelatihan maupun mengajukan pertanyaan baik mengenai proses pengolahannya maupun teknologi sederhana cara pembuatannya sehingga terjadi diskusi dua arah yang aktif . pengetahuan dan keterampilan peserta bertambah yang nantinya dapat dikembangkan menjadi unit usaha oleh ibu-ibu PKK dan anggota kelompok Tani Aban Sari. Peserta pelatihan dikoordinir oleh Bapak Made Supartha selaku Ketua Kelompok Tani.
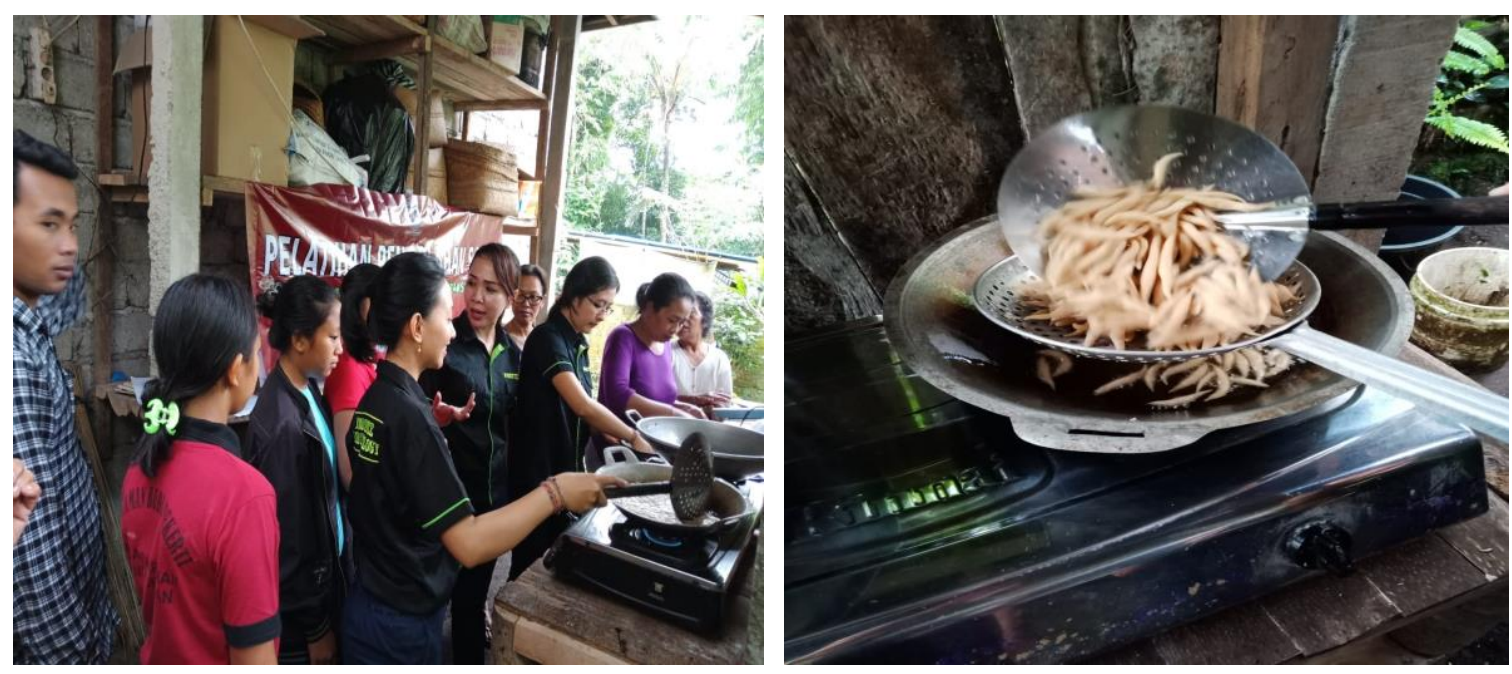

Gambar 1. Foto pembuatan stiksagu keju

\subsection{Pengemasan dan Pelabelan}

Mengingat akan pentingnya fungsi dari pengemasan dan pelabelan, maka kami memberikan penyuluhan dan praktek langsung cara mengemas produk yang mereka telah hasilkan. Pemberian merek dagang tak kalah pentingnya yang memiliki 2 fungsi utama yaitu sebagai identitas bagi produk dan sebagai pembeda produk dalam bisnis yang dimiliki dengan para pesaing. Manfaat merek dalam suatu bisnis selain sebagai identitas dan membedakan dengan pesaing dapat juga untuk meningkatkan penjualan, dapat membangun loyalitas, komunikasi pasar menjadi (Wilopo, 2007).

Untuk desain label kemasan pada produk kami membantu mendesainkannya sebelumnya, dalam hal ini tetap kami komunikasikan pada saat penyuluhan untuk menerima masukan dari anggota KT. Penyuluhan dan praktek langsung pengemasan serta pelabelan produk jamur crispy dilaksanakan tanggal 28 Juli 2018. Pengemas pada stik sagu keju adalah plastk poli etilen dn juga kaleng plastik. . 

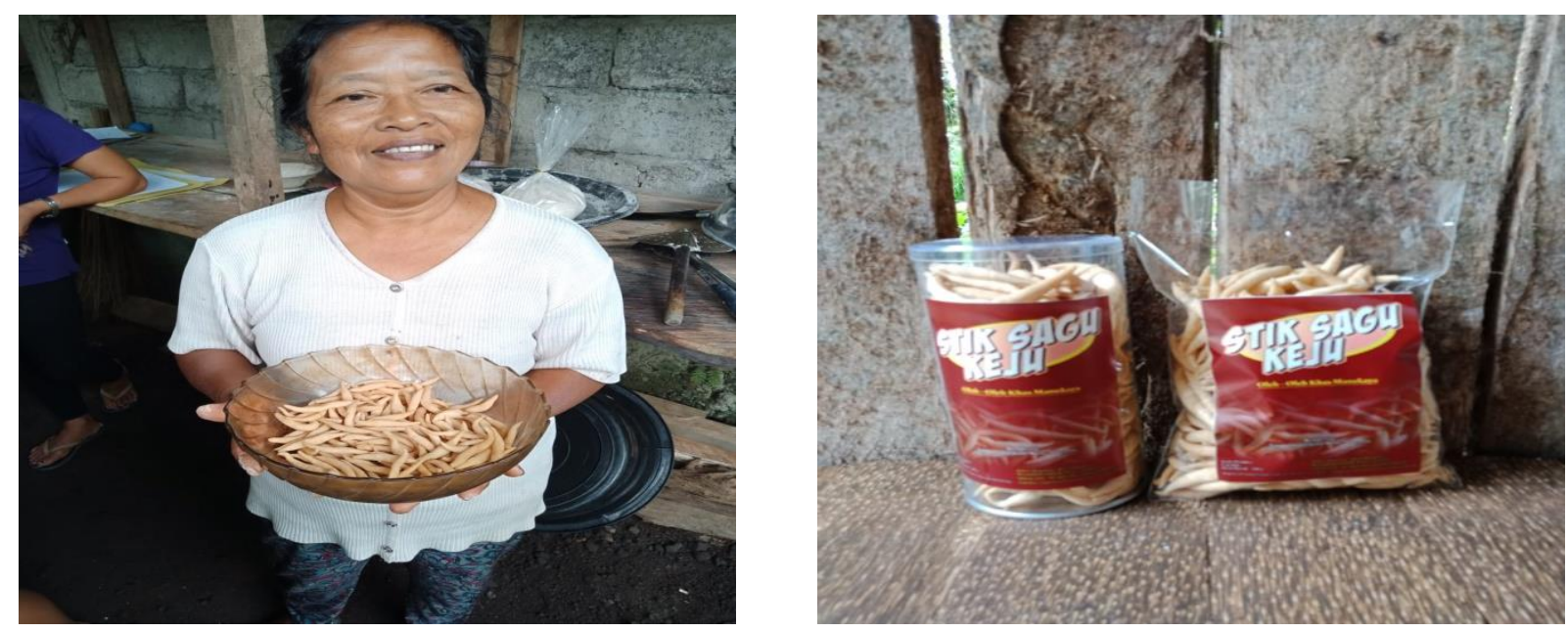

Gambar 2. Foto stik sagu keju yang dikemas dengan plastik Polietilen dengan label

\section{Tercapainya tujuan}

Berdasarkan tujuan dari kegiatan pelatihan pengolahan tepung sagu menjadi berbagai produk olahan yang bernilai gizi tinggi, kaya serat, protein, daya simpan lama dan alternative deiversifikasi poduk olahan pangan. Seperti diolah menjadi stik keju. Selain memperkenalkan dan memberikan pengetahuan tambahan kepada masyarakat tentang teknologi pengolahan tepung sagu menjadi berbagai produk olahan sehingga masyarakat dapat mengembangkan industri rumah tangga selain karena sagu kaya akan serat, karbohidrat, mineral dan protein sehingga akan dapat meningkatkan nilai ekonomis dari tepung sagu itu sendiri. Disamping itu dengan diolahnya tepung sagu menjadi stik sagu keju akan meningkatkan umur simpan dari tepung sagu itu sendiri utamanya pada saat panen raya. Selanjutnya masyarakat dapat mengembangkan usaha/industri rumah tangga sehingga kesejahteraan masyarakat dapat ditingkatkan. Untuk mencapai tujuan tersebut dilakukan kegiatan dengan memberikan penyuluhan tentang manfaat tepung sagu disertai dengan demonstrasi cara pembuatan berbagai produk olahannya. Teknologi pengemasan secara sederhana juga diberikan kepada anggota kelompok tani desa manukaya guna memberikan identitas produk dan meningkatkan nilai estetika produk itu sendiri disamping akan memperpanjang umur simpan karena mencegah serta melindungi produk dari kontaminasi terhadap mikroba..

\section{Tercapainya Sasaran}

Dalam kegiatan Pengabdian Kepada Masyarakat ini peserta yang hadir sesuai dengan khalayak sasaran yaitu ibu-ibu /Bapak-Bapak anggota Kelompok tani yang berjumlah 18 orang dan dibagi menjadi 2 kelompok dengan anggota masing masing 10-8 orang. Hal ini menunjukkan bahwa kegiatan ini berhasil mencapai sasaran yang diharapkan.

\section{Tercapainya Target}

Terlaksananya kegiatan pengabdian pengolahan tepung sagu menjadi Stik sagu keju di Desa manukaya, Kecamatan Tampaksiring, Kabupaten Gianyar meliputi penyuluhan, pelatihan pengolahan produk, pengemasan dan pelabelan, sumbangan alat, monitoring dan evaluasi yang dilaksanakan dari akhir juni sampai akhir Agustus 2018 tanpa ada hambatan yang berarti, maka target dari kegiatan ini telah tercapai lebih dari $70 \%$ sesuai dengan yang direncanakan..

\section{Tercapainya Manfaat}

Suksesnya pelaksanaan seluruh kegiatan pengabdian kepada masyarakat ini tentunya mempunyai manfaat yang cukup baik bagi masyarakat pada umumnya, pelaku industri rumah tangga khususnya dan juga ibu-ibu/Bapak-bapak anggota Kelompok Tani Abian sari dan ibu-ibu PKK di Desa Manukaya. Adanya peningkatan pengetahuan KT tentang pengolahan tepung sagu, KT dapat melakukan pengolahan sendiri serta dapat meningkatkan pendapatan dan kesejahteraan masyarakat serta meningkatkan statusnya menjadi UKM 

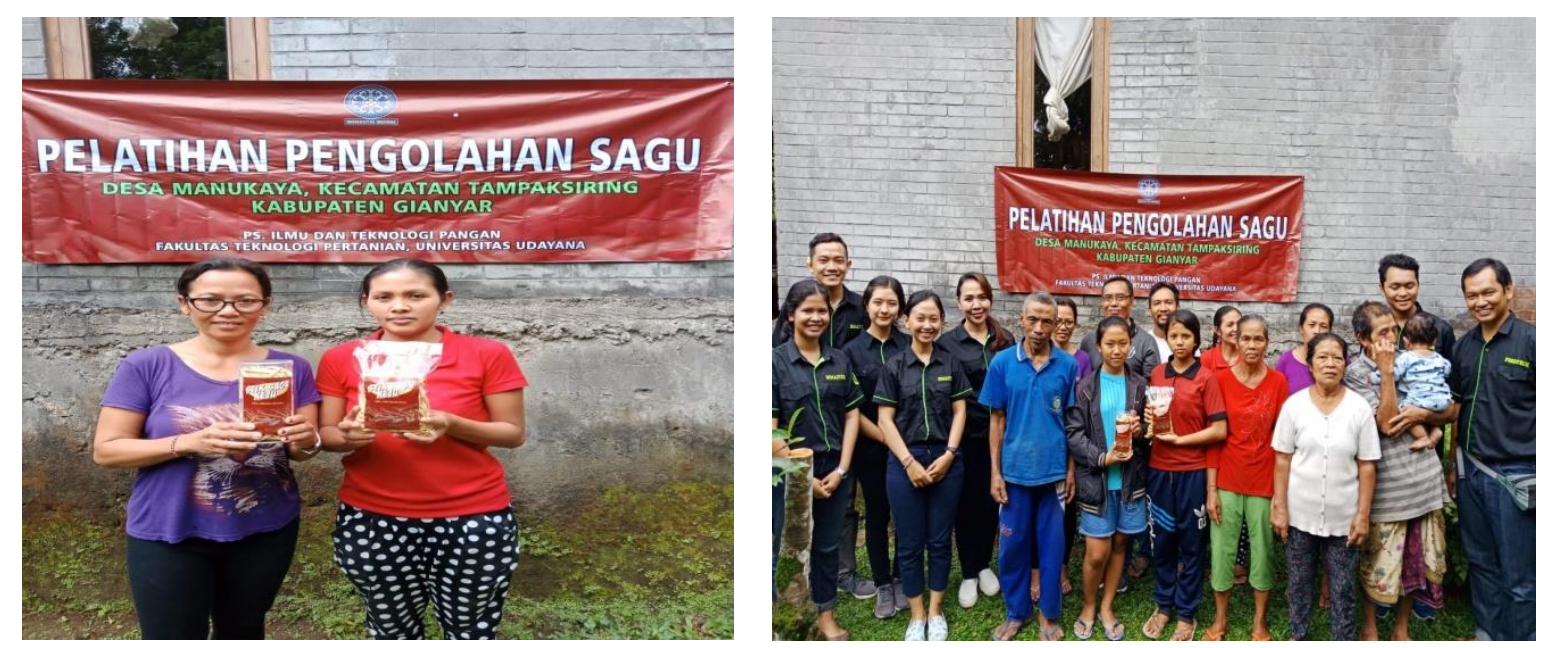

Gambar 3. Foto bersama usai pelatihan

\section{KESIMPULAN DA N SARAN}

\subsection{Kesimpulan}

1. Kegiatan pengabdian ini dilaksanakan dalam bentuk penyuluhan dan pelatihan pengolahan tepung sagu menjadi stik sagu keju pada kelompok Tani Abian Sari di Banjar Penendengan, Desa Manukaya, Tampaksiring, Kabupaten Gianyar

2. Pelatihan teknik pengemasan dan pelabelan juga diberikan pada KT Abin Sari Kegiatan pelatihan dapat dikatakan berhasil, karena dapat terlaksana dengan baik dan respon masyarakat yang sangat positif yang terlihat dari keaktifan peserta selama diskusi dan pelatihan berlangsung.

3. Kegiatan ini sudah terlaksana $100 \%$ dan para KT mampu memproduksi stik sagu keju Merk dagang STIK SAGU KEJU guna mencapaian tujuan untuk menaikan status Kelompok tani menjadi UKM

\subsection{Saran}

Melihat respon masyarakat yang tinggi terhadap pelatihan Pengolahan tepung sagu menjadi stik sagu keju di Desa Manukaya, Kecamatan Tampaksiring, Kabupaten Gianyar, maka diperlukan kegiatan serupa di daerah-daerah lain. Kegiatan ini akan lebih bermanfaat apabila dilakukan secara simultan dengan penyuluhan mengenai pemasaran dari produk yang dihasilkan.

\section{Ucapan Terimakasih}

Kepada DIPA PNBP Universitas Udayana Sesuai dengan Surat Penugasan Pelaksanaan Pengabdian Kepada Masyarakat Nomor 674-90/UN 14.4A/PM/2017, tanggal 12 Juli 2017

\section{DAFTAR PUSTAKA}

Anonimus. 2001. Teknologi Tepat Guna Agroindustri Kecil Sumatera Barat, Hasbullah, Dewan Ilmu Pengetahuan, Teknologi dan Industri Sumatera Barat.

Anonimus. 2010. Olahan Sagu Liputan6.com, Badung. 
PELATIHAN PENGOLAHAN DAN PENGEMASAN TEPUNG SAGU MENJADI STIK SAGU KEJU DI KAWASAN RUMAH PANGAN LESTARI (KRPL) DESA MANUKAYA KECAMATAN TAMPAKSIRING KABUPATEN GIANYAR

Anonimus . 2017 a. http://www.gerbangsadumandara.provbali.info/kecamatan-tampaksiring/desamanukaya.html. Diakses 20 Desember 2017

Anonimus.2017b.http://www.desamandara.baliprov.go.id/desa-manukaya Diakses 20 November $\underline{2017}$

Anonimus. 2017c. https://id.wikipedia.org/wiki/Manukaya,_Tampaksiring,_Gianayar. Diakses 20 November 2017

Anonim. 2018. http://resepindonesia.net/resep-stik sagu keju-Sagu-sederhana/. Diakses 10 januari 2018

Desrosier, N.W., 1988. Teknologi Pengawetan Pangan. UI-Press, Jakarta.

Julianti, E., Mimi, N. 2006. Teknologi Pengemasan. Bahan Ajar Fakultas Pertanian Universits Sumatera Utara

Johan, M. 2014. kandungan Nutrisi. Universitas hasanuddin , makassar 